\title{
SELECTED FIRM CHARACTERISTICS AND FINANCIAL INTERMEDIATION EFFICIENCY OF DEPOSIT TAKING SAVING AND CREDIT CO-OPERATIVE SOCIETIES IN KENYA
}

\author{
KARIUKI*, P. W \\ University of Embu, P.O Box 6-60100 Embu, KENYA
}

Received :January 2018; Revised: March 2018; Accepted: April 2018

\begin{abstract}
There has been growing concerns over the financial soundness of SACCOs with a few having collapsed in the recent past. Empirical evidence indicates that there exists a strong association between efficiency and stability of financial institutions and that an efficient banking sector is better able to withstand negative shocks in case of financial crises. The study first sought to evaluate the financial intermediation efficiency of deposit taking SACCOs (DTSS) and subsequently determine the relationship between selected firm characteristics and financial intermediation efficiency. Specifically, the relationship between asset quality, income diversification, profitability \& size and financial intermediation efficiency was assessed. A balanced panel data for 103 DTSs over the period 2011-2014 was collected and analyzed using a two staged methodology. In the first stage, efficiency scores were generated using data envelopment analysis (DEA). DEA Computer Program Version 2.1 was used to generate the efficiency scores. In the second stage, firm characteristics were regressed on the efficiency scores using fixed effects panel regression model. The bias corrected efficiency score were used instead of conventional DEA scores and incorporated into EViews version 8 for regression analysis. Fixed effect model with robust standard errors was used for analysis. The study revealed that asset quality had a direct relationship with intermediation efficiency. This implies that as the asset quality improves, efficiency of a DTS increases. Diversification was found to be hurting efficiency. More profitable DTSs were found to be more efficient indicating that profitability is efficiency enhancing. The results also revealed a positive relationship between size and efficiency. The study recommends that managers and policy makers should concentrate on how to improve the managerial efficiency and also increase the size of SACCOS. Policy framework should also be directed towards encouraging DTSS to consolidate their operations and limit their diversification into noninterest income.
\end{abstract}

Keywords: Data Envelopment Analysis, Firm Characteristics, Intermediation Efficiency

*Correspondence to: P. Kariuki: University of Embu, 1-1. Email: p.kariuki3@gmail.com

\section{NTRODUCTION}

The Savings and Credit Cooperative Societies (SACCOs) play a critical role in Kenya's financial sector in terms of access, savings mobilization and wealth creation. They focus on savings mobilization for onward lending to members. The subsector is seen as a critical player in achieving the $10 \%$ annual economic growth envisaged by the Kenya's economic blueprint, Vision 2030 (SASRA, 2013). The SACCO subsector in Kenya is two-tiered with deposit taking and non deposit taking SACCOs. The

KARIUKI, P. W: Selected firm characteristics and financial intermediation efficiency of deposit taking saving and credit cooperative societies in Kenya 
deposit taking SACCOs (DTSs) operate both Back Office Services Activity (BOSA) and Front Office Services Activity (FOSA). This makes them closely mirror the operation of commercial banks (ROK, 2012). Such SACCOs are licensed and supervised by SASRA under the SACCO Societies Act, 2008.

Recent developments in the financial markets have motivated SACCOs to reorient their operations. SACCOs have continually developed new products and services which now mirror the operations of commercial banks (ROK, 2012). The diversification into nontraditional markets and breaking the common bond however exposes SACCOs to systemic risks that threaten their stability. There exists empirical evidence indicating that there exists a strong association between efficiency and stability of financial institutions. Rozzani and Rahman (2013) observed that inefficiency is the leading cause of bank failure. According to Delis and Papanikolaou (2009), an efficient banking sector is better able to withstand negative shocks thus contributes to the stability of the financial system. A stable financial system contributes to the wellbeing of the whole economy.

There has been considerable development on efficiency measurement of financial institutions in the recent past. A review by Sharma, Sharma and Barua (2013) on studies done over the period 1994-2013 globally revealed an upsurge of studies on banking efficiency after 2010. The study revealed growing popularity of the frontier practices in evaluation of efficiency in banking. The measurement of efficiency can be traced to Koopmans (1951) and Debreu (1951). It was later advanced by Farrel (1957) who proposed that efficiency of a firm consists of two components; technical efficiency and allocative efficiency. Technical efficiency reflects the ability of a firm to obtain maximal outputs from a given set of inputs whereas allocative efficiency reflects the ability of a firm to use the inputs in optimal proportions, given their respective prices (Farrel, 1957). Within Farrel (1957) proposition, there are two categories of efficiency measurement approaches; parametric and non parametric. Parametric approaches include; distribution free approach (DFA) (Berger, 1993), stochastic frontier analysis (SFA) (Aigner, et al., 1977) and thick frontier approach (TFA). Non parametric approaches include; data envelopment analysis (DEA) (Charnes, et al., 1978) and free disposal hull (FDH) (Deprins, et al., 1984) among. The study of efficiency in financial institutions is enhanced by investigating environmental variables that are likely to influence efficiency. This involves a twostage estimation procedure where efficiency scores are generated and then regressed on some environmental variables. The term "environmental variables" is usually used to describe factors which could influence the efficiency of a firm (Sufian, 2009). According to Sharma et al., (2013), the efficiency determining factors are categorized into three categories: bank (firm) specific variables, macro economic variables and regulatory variables. Arora (2014) agrees arguing that the reasons for efficiency differences among banks may be attributed to both internal bank-specific forces and external macro-economic forces.

Most studies on efficiency have concentrated on commercial banks hence the term "bank characteristics" is widely used instead of "firm characteristics". Firm characteristics refer to the aspects of a firm that are affected by firm-level management. Arora (2014) argues that while differences in efficiency across banks may be due to forces internal to the banks itself such as objectives, bank conduct, size, ownership styles and managerial capabilities of banks; it may not be possible to account for all bank-specific determinants due to measurement challenges. For this reason the current study narrowed to those characteristics that are observable from the financial statements.

KARIUKI, P. W: Selected firm characteristics and financial intermediation efficiency of deposit taking saving and credit cooperative societies in Kenya 


\section{METHODS}

The study focused on deposit taking SACCOs (DTSs) in Kenya. According to SASRA (2015), a total of 181 DTSs were licensed to undertake deposit-taking SACCO business by the end of the year 2014. Though the study envisaged a census, data was available for 103 DTSs. A balanced panel data for the period 2011-2014 was collected and analyzed. The choice of the period was informed by the transition period into prudential regulation regime which commenced in 2010 following the enactment of the SACCO Societies Act, 2008. The secondary data was collected from the financial statements filed with the regulator, SASRA.

A two stage analysis was adopted for this study. In the first stage efficiency scores were generated using the data envelopment analysis DEA methodology. The study adopted DEA due to its attractive features. First, it places no constraint on the functional form of the production relationship. Compared with statistical regression analysis, it focuses on the individual observations rather than on population averages. Secondly, it concentrates on revealed best-practice frontiers, rather than on the central tendency properties of frontiers (Burki \& Niazi, 2010; Kamau, 2011; Othman, et al., 2014; Paxton, 2006; Zheng, et al., 1998).

In the second stage, a panel regression model was used to determine the relationship between DEA efficiency score and selected firm characteristics. According to Simar and Wilson (1998), efficiency scores generated by DEA models are clearly dependent on each other in statistical sense. This renders the conventional regression procedure invalid due to the violation of the classical linear regression assumption. To cure the inherent dependency problem, the study, similar to Casu and Molyneux (2003), substituted the conventional DEA efficiency scores with bootstrapped efficiency scores. The bootstrapping was carried out using rDEA package rooted in R statistical package.

The envisaged panel model was as follows.

$T E F F_{i t}=\propto_{0}+\beta_{1} A S Q_{i t}+\beta_{2} D I V_{i t}+\beta_{3} P R O F_{i t}+\beta_{4} S I Z E_{i t}+\varepsilon_{i t}$

Where $\quad \mathrm{i}=1,2, \ldots 135$, and $\mathrm{t}=1,2,3,4$

Table 1: Summary of the research variables data measures

\begin{tabular}{|c|c|c|}
\hline Variable & Proxy & Measure \\
\hline $\begin{array}{l}\text { Dependent Variable } \\
\text { Intermediation } \\
\text { Efficiency }\end{array}$ & TEFF & $\frac{\text { welghed swm of oweques }}{\text { weighted sum of inpwes }}$ \\
\hline \multicolumn{3}{|l|}{ Independent Variables } \\
\hline Assets Quality & ASQ & Non-performing Loans to Gross loans \\
\hline Income Diversification & DIV & Non-interest Income to Total Assets \\
\hline Profitability & PROF & Net income after tax to Total Assets \\
\hline Size & SIZE & Log of total assets \\
\hline
\end{tabular}

\section{RESULTS AND DISCUSSION}

KARIUKI, P. W: Selected firm characteristics and financial intermediation efficiency of deposit taking saving and credit cooperative societies in Kenya 
Journal of Applied Sciences, Engineering and

Technology for Development. Volume 2, Issue 1

\section{Correlation Analysis of DEA Inputs and Outputs}

As noted, objective of the study was to evaluate intermediation efficiency of DTSs and thus adopted the intermediation approach of DEA. The study aimed at evaluating how efficiently DTSs collate member's deposit, employs capital and labour to advance loans to the members and grow investments. Consequently, total deposits, labour cost and core capital were selected as inputs whereas gross loans and investments as outputs. Karl Pearson's (product moment) correlation coefficient was used to evaluate the appropriateness of the selected inputs and outputs as recommended by Kamau (2011). Table 2 presents the correlation coefficients among selected inputs and outputs. The results revealed strong positive correlations between input and output selected. This confirmed the appropriateness of the selected input and output variables.

Table 2: Karl Pearson's Correlation Coefficient among inputs and outputs

\begin{tabular}{|c|c|c|c|c|c|}
\hline & $\begin{array}{l}\text { D } \\
\tilde{\Xi} \\
0 \\
0 \\
0 \\
0 \\
\dot{0}\end{array}$ & 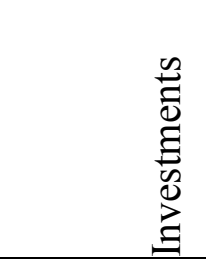 & $\begin{array}{l}\stackrel{0}{0} \\
0 \\
0 \\
0 \\
0 \\
0 \\
0 \\
0 \\
0\end{array}$ & 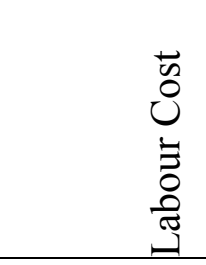 & $\begin{array}{l}\overline{0} \\
\overline{0} \\
0 \\
0 \\
0 \\
0\end{array}$ \\
\hline Gross Loans & 1 & & & & \\
\hline Investments & $\begin{array}{c}0.6409 * * * \\
0.0000\end{array}$ & $\begin{array}{c}1 \\
-----\end{array}$ & & & \\
\hline Total Deposit & $\begin{array}{c}0.9725 * * * \\
0.0000\end{array}$ & $\begin{array}{c}0.6117 * * * \\
0.0000\end{array}$ & $\begin{array}{c}1 \\
-----\end{array}$ & & \\
\hline Labour Cost & $\begin{array}{c}0.8751 * * * \\
0.0000\end{array}$ & $\begin{array}{c}0.6171 * * * \\
0.0000\end{array}$ & $\begin{array}{c}0.8836^{* * *} \\
0.0000\end{array}$ & $\begin{array}{c}1 \\
-----\end{array}$ & \\
\hline Core Capital & $\begin{array}{c}0.6788 * * * \\
0.0000\end{array}$ & $\begin{array}{c}0.4679 * * * \\
0.0000\end{array}$ & $\begin{array}{c}0.6982 * * * \\
0.0000\end{array}$ & $\begin{array}{c}0.6892 * * * \\
0.0000\end{array}$ & $\begin{array}{c}1 \\
-----\end{array}$ \\
\hline
\end{tabular}

$*(* *)(* * *)$ significant at $10 \%(5 \%)(1 \%)$.

\section{Intermediation Efficiency}

The study generated the DEA efficiency score in the first stage using variable return to scale (VRS). Variable return to scale is preferred due do its realistic assumption that all firms do not operate under optimal scale as opposed to constant return to scale (CRS) which is only appropriate when firms are operating at an optimal scale. However, to reveal the main cause of inefficiencies in a firm, both CRS and VRS efficiency scores are determined. Coelli, et al., (2005) argues that CRS efficiency scores are decomposed into two components; Scale efficiency and VRS TE ("pure" technical efficiency). The efficiency measure corresponding to VRS assumption represents pure technical efficiency (PTE) which measures inefficiencies due to only managerial underperformance whereas scale efficiency indicates whether the DMU (DTS) produces at the most efficient size (Lothgren \& Tambour, 1999; Yadav \& Katib, 2015).

KARIUKI, P. W: Selected firm characteristics and financial intermediation efficiency of deposit taking saving and credit cooperative societies in Kenya 
The results presented in Table 3 reveal that there has been a sustained increase in intermediation efficiency during the transition period. In 2011, the technical efficiency was 0.646 and gradually increased to 0.707 in 2014. This depicts improvement in efficiency as more and more DTSs attained regulatory compliance. An average of $67 \%$ (0.677) over the four years period indicate that DTSs are capable of increasing their outputs (loan to members and investments) by about $32 \%$ without any additional increase in inputs (deposits, labour and capital). This results mirrored those of Mwangi (2014) who found an overall average efficiency of 0.775 in a study of SACCOs in Kenya for the period 2009-2013. Kamau (2011), on the other hand found an average efficiency of $70 \%$ in commercial banks in Kenya for the period 1997-2009 while Nasieku, Kosimbei and Obwogi (2013) found an average of 84\% in a similar study over the period 2001-2011. The results indicate that commercial banks are relatively better in terms of intermediation efficiency compared to DTSs though the studies covered different time periods.

Table 3: Summary Efficiency Scores over the Years

\begin{tabular}{|c|c|c|c|}
\hline Year & $\begin{array}{l}\text { Constant Return to Scale } \\
\text { (CRS) } \\
\text { Efficiency }\end{array}$ & $\begin{array}{l}\text { Variable Return to Scale } \\
\text { (VRS) } \\
\text { Efficiency }\end{array}$ & $\begin{array}{l}\text { Scale } \\
\text { Efficiency }\end{array}$ \\
\hline 2011 & 0.541 & 0.646 & 0.849 \\
\hline 2012 & 0.540 & 0.648 & 0.846 \\
\hline 2013 & 0.639 & 0.706 & 0.907 \\
\hline 2014 & 0.626 & 0.707 & 0.885 \\
\hline Mean & 0.587 & 0.677 & 0.872 \\
\hline
\end{tabular}

\section{Regression Analysis}

\section{Diagnostic Tests for Panel Data}

The study used panel data which has both cross sectional and time series characteristics. Panel data estimation models include; pooled ordinary least square (OLS), fixed effects model (FEM) and random effects model (REM). To identify the best model for the current study, diagnostic tests were carried out. Breusch-Pagan Lagrange multiplier (LM) test was used to decide whether pooled OLS or random effects model was appropriate. It revealed that the pooled OLS regression model was not appropriate for the study. The Hausman test showed that the best model for the study was the fixed effects regression model. Results further revealed that there were no significant time affects and therefore no need for introducing dummy variables. The Modified Wald test showed that there existed heteroskedasticity. Presence of heteroscedasticity makes the standard errors of the estimates to be biased. The study therefore used robust standard errors to correct for the presence of heteroscedasticity (Antonie, et al., 2010; Hoechle, 2007). Wooldridge Drukker test was used to test for presence of serial correlation with the results indicating absence of serial correlation.

\section{Regression Results}

Supported by the diagnostic tests conducted on the panel data, the best model for analysis was found to be fixed effect model with robust (white's cross-section heteroscedastic consistent) standard errors. The results are presented in table 4 . The results shows that assets quality have a negative beta coefficient (- 0.3434) implying a 


\section{Journal of Applied Sciences, Engineering and Technology for Development, JASETD, Volume 2, Issue 1}

significant inverse $(\mathrm{p}=0.0000<0.05)$ relationship between the ratio of nonperforming loans to total loans and financial intermediation efficiency. This reveals a positive relationship between asset quality and intermediation efficiency. It means that as asset quality improves (ratio on non performing loans to total loans reduces), intermediation efficiency of a DTS improves. Similar results were reported in earlier studies (Arora, 2014; Burki \& Niazi, 2010; Kiyota, 2011; and Sufian, 2009).

The direct relationship between asset quality and intermediation efficiency (negative coefficient) depicts the need for continuous monitoring of borrowers to ensure credit is repaid on timely basis. Swamy (2012) posits that the problem of nonperforming loans is synonymous to functional inefficiency of financial intermediaries and is believed to be the major cause of the economic stagnation. Michael, et al., (2006) emphasized that poor assets quality affect operational efficiency of financial institutions which in turn affects profitability, liquidity and solvency position of banks. Sufian (2009) further posits that banks approaching failure tend to have low cost efficiency and experience poor asset quality. The study therefore points out that significant managerial efforts should be expended on improving asset quality. This would enhance the intermediation efficiency.

On diversification, the results revealed a negative $(\beta=-0.3441)$ significant $(p=0.0147<0.05)$ between income diversification and intermediation efficiency. The empirical results are consistent with those of Elyasiani and Wang (2012) and Huang and Chen (2006) but contradict those of Maghyereh and Awartani (2014) and Sufian (2009). The inverse relationship implies that income diversification hurts efficiency through more idiosyncratic risk and decreased incentives to monitoring. The increase in the number of activities is generally associated with increased opaqueness and information asymmetry and agency problems (Elyasiani \& Wang, 2012). The core mandate of DTSs is to collate deposit and advance loan to members at favorable terms. Diversification into other activities such as provision of ATM services, salary processing and over the counter operations, may hurt efficiency with which they undertake their core mandate. Additionally; the size of DTSs could act as a bottleneck, with a small DTSs, no significant economies of scale are realized with income diversification. Goddard, Mckillop and Wilson (2008) suggest that where credit unions neither have sufficient scale nor the requisite expertise to diversify, they ought to limit diversification and specialize as vehicles for savings and loans.

On profitability, the results showed a positive $(\beta=1.1541)$ significant $(p=0.0029<0.05)$ relationship between profitability and intermediation efficiency. The findings corroborate those by Arora (2014), Maghyereh and Awartani (2014), Alrafadi, Kamaruddin and Yusuf (2014), Othman, et al., (2014), Srairi (2010) and Sufian (2009). However, Gulati (2015) found negative relationship. It reveals that most efficient DTSs were on an average characterized by higher profitability. There are a number of explanations that may be advanced on this phenomenon. First, profitable DTSs are capable of employing and retaining high caliber staff members and investing in technology which is efficiency enhancing. Secondly, they are capable of providing incentives to their staff thus motivating them to perform even better and reduce wastages. Lastly, more profitable DTSs are capable of attracting more deposits from members due to the returns earned. This enables then to provide more loans and investment opportunities to members.

The size of DTSs was found to have a positive and significant relationship with financial intermediation efficiency. The results of the study were consistent with a number of earlier studies (Delis \& Papanikolaou, 2009; Karray \& Chichti, 2013; Kiyota, 2011; Mwangi, 2014; Wheelock \& Wilson, 2011). Arora (2014) however

KARIUKI, P. W: Selected firm characteristics and financial intermediation efficiency of deposit taking saving and credit cooperative societies in Kenya 
found no conclusive evidence regarding a relationship between size and efficiency. The results suggest that DTSs have not fully optimized their scale of operation. Continued expansion would therefore be efficiency enhancing. Rozzani and Rahman (2013) posits that large banks (DTSs) are capable of mobilizing more funds and generating high returns for its depositors and equity holders due to its diversification, which is achieved from having more resources. With more resources, larger DTSs are able to finance large numbers of profitable investment opportunities and have better access to investment activities. Additionally, DTSs with large asset base are capable of investing in efficiency enhancing technology and also engaging in promotion activities. This results into ability to mobilize even more resources. On the other side, the effect of size could be negative for banks that are extremely large due to bureaucracy (Nigmonov, 2010).

Table 4: Fixed effects regression on selected firm characteristics and financial intermediation efficiency

\begin{tabular}{lrrrr}
\hline Variable & Coefficient & Std. Error & t-Statistic & Prob. \\
\hline Constant & -2.0719 & 0.4892 & -4.2351 & 0.0000 \\
Asset quality & -0.3441 & 0.0604 & -5.6962 & 0.0000 \\
Diversification & -0.8670 & 0.3534 & -2.4531 & 0.0147 \\
Profitability & 1.1541 & 0.3841 & 3.0044 & 0.0029 \\
Size & 0.2745 & 0.0567 & 4.8376 & 0.0000 \\
R-squared & 0.5773 & Mean dependent var & 0.3497 \\
Adjusted R-squared & 0.4304 & S.D. dependent var & 0.1918 \\
S.E. of regression & 0.1447 & Akaike info criterion & -0.8090 \\
Sum squared resid & 6.3901 & Schwarz criterion & 0.2353 \\
Log likelihood & 273.6487 & Hannan-Quinn criter. & -0.3959 \\
F-statistic & 3.9294 & Durbin-Watson stat & 2.3858 \\
Prob(F-statistic) & 0.0000 & & & \\
\hline
\end{tabular}

\section{CONCLUSION}

The study investigated the relationship between selected firm characteristics and financial intermediation efficiency of deposit taking SACCO societies in Kenya. The study employed a two staged methodology. In the first stage, the financial intermediation efficiency of DTSs was evaluated using a non parametric DEA approach. The results revealed a sustained increase in financial intermediation efficiency during the transition period. This implied that DTSs improved their intermediation efficiency as they gradually complied with prudential regulations. The study concludes that compliance with prudential regulations enhanced intermediation efficiency. Over the study period; the scale efficiency was higher than pure technical efficiency. This implies that inefficiencies in DTSs were due to managerial underperformance rather than suboptimal size.

In the second stage of analysis, the study sought to determine the relationship between selected firm characteristics and the efficiency. In case of asset quality the relation was found to be direct implying that as the asset quality increases, efficiency of a DTS increases. Diversification was found to be hurting efficiency. As net interest income increases, the level of efficiency was found to decline. More profitable DTSs were 
found to be more efficiency indicating that profitability in efficiency enhancing. The study also revealed a positive relationship between size and efficiency.

The study recommends that managers and policy makers should concentrate on how to improve the managerial efficiency and also increase the size of SACCOs. Policy framework should also be directed towards encouraging DTSs to consolidate their operations and limit their diversification into non-interest income. Continued expansion of the loan book would therefore be encouraged. A direct relationship between profitability and intermediation efficiency imply that management ought to focus on maximizing profitability of the DTS and in the process enhance efficiency. Improved efficiency could also be realized if the regulator could continually monitor the profitability of DTSs.

\section{REFERENCES}

Aigner, D., Lovell, C. A. K., \& Schmidt, P. (1977). Formulation and estimation of stochastic frontier production function model. Journal of Econometrics, 6(1), $21-37$.

Alrafadi, K., Kamaruddin, B., \& Yusuf, M. (2014). Efficiency and Determinants in Libyan Banking. International Journal of Business and Social Science, 5(5), $156-168$.

Antonie, M. D., Cristescu, A., \& Cataniciu, N. (2010). A Panel Data Analysis of the Connection between Employee Remuneration , Productivity and Minimum Wage in Romania. In 11th WSEAS Int. Conf. MCBE (pp. 134-139).

Arora, P. (2014). Reforms , Ownership and Determinants of Efficiency: An Empirical Study of Commercial Banks in India. Journal of Emerging Market Finance, 13(1), 103-138. doi:10.1177/0974910114534026

Berger, A. (1993). 'Distribution-free' estimates of efficiency in the US banking industry and tests of the standard distributional assumptions. Journal of Productivity Analysis, 4(3), 261-292.

Burki, A. A., \& Niazi, G. S. K. (2010). Impact of financial reforms on efficiency of state- owned, private and foreign banks in Pakistan. Applied Economics, 42(24), 37-41. doi:10.1080/00036840802112315

Casu, B., \& Molyneux, P. (2003). A Comparative Study of Efficiency in European Banking. Applied Economics, 35(17), 1865-1876. doi:10.1080/0003684032000158109

Charnes, A., Cooper, W. W., \& Rhodes, E. (1978). Measuring efficiency of decision making units. European Journal of Operations Research, 2, 429-444.

Coelli, T., Rao, D., O’Donnell, C., \& Battese, G. (2005). An Introduction to Efficiency and Productivity Analysis. Springer Science \& Business Media.

Debreu, G. (1951). The Coefficient of Resource Utilization. Econometrica: Journal of the Econometric Society, 273-292.

KARIUKI, P. W: Selected firm characteristics and financial intermediation efficiency of deposit taking saving and credit cooperative societies in Kenya 
Delis, M., \& Papanikolaou, N. (2009). Determinants of bank efficiency: Evidence from a semi-parametric methodology. Managerial Finance, 34(3), 146-159. doi:doi.org/10.1108/03074350810848036

Deprins, D., Simar, L., \& Tulkens, H. (1984). Measuring labour-efficiency in post offices. In M. Marchand, P. Pestiau, \& H. Tulkens (Eds.), The Performance of Public Enterprises: Concepts and Measurements. Holland, Amsterdam.

Elyasiani, E., \& Wang, Y. (2012). Bank holding company diversification and production efficiency. Applied Financial Economics, 22(17), 1409-1428. doi:10.1080/09603107.2012.657351

Farrel, M. J. (1957). The Measurement of Productive Efficiency. Journal of the Royal Statistical Society, 120(3), 253-290. doi:10.2307/2343100

Goddard, J., Mckillop, D., \& Wilson, J. O. S. (2008). The Diversification and Financial Performance of US Credit Unions. Journal of Banking \& Finance, 32, 1836-1849. doi:10.1016/j.jbankfin.2007.12.015

Gulati, R. (2015). Trends of cost efficiency in response to financial deregulation: the case of Indian banks. Benchmarking: An International Journal, 22(5). doi:org/10.1108/BIJ-06-2013-0065

Hoechle, D. (2007). Robust Standard Errors for Panel Regressions with CrossSectional Dependence. The Stata Journal, 7(3), 281-312.

Huang, L. W., \& Chen, Y. K. (2006). Does Bank Performance Benefit from Nontraditional Activities? A Case of Non-interest Incomes in Taiwan Commercial Banks. Asian Journal of Management and Humanity Sciences, 1(3), 359-378. Retrieved from http://210.60.31.132/ajmhs/no3/01-mhs06024.pdf

Kamau, A. W. (2011). Intermediation Efficiency and Productivity of the Banking Sector in Kenya. Interdisciplinary Journal of Research in Business, 1(9), 12-26.

Karray, S., \& Chichti, J. (2013). Bank Size and Efficiency in Developing Countries: Intermediation Approach versus Value Added Approach and Impact of NonTraditional Activities. Asian Economic and Financial Review, 3(5), 593-613.

Kiyota, H. (2011). Efficiency of Commercial Banks in Sub-Saharan Africa: A Comparative Analysis of Domestic and Foreign Banks (No. 58). Helsinki.

Koopmans, T. C. (1951). An Analysis of Production as an Efficient Combination of Activities (No. 13). New York: Wiley.

Lothgren, M., \& Tambour, M. (1999). Testing scale efficiency in DEA models: a bootstrapping approach. Applied Economics, 31(10), 1231-1237. doi:10.1080/000368499323445 
Maghyereh, A., \& Awartani, B. (2014). The effect of market structure, regulation, and risk on banks efficiency. Journal of Economic Studies, 41(3), 405 - 430. doi:10.1108/JES-05-2012-0067

Michael, J., Vasanthi, G., \& Selvaraju, R. (2006). Effect of Non-Performing Assets on Operational Efficiency of Central-Cooperative Banks. Indian Economic Panorama, 16(3), 33-39.

Mwangi, M. (2014). The Influence of Members' Income and Conduct of Saccos in the Relationship between Characteristics and Efficiency of Saccos in Kenya. Unpublished PhD Thesis; UON.

Nasieku, T., Kosimbei, G., \& Obwogi, J. (2013). Intermediation Efficiency and Productivity of Commercial Banks in Kenya; a Data Envelopment and Malmquist Productivity Index Analysis. Economics and Finance Review, 3(01), $1-13$.

Nigmonov, A. (2010). Bank Performance and Efficiency in Uzbekistan. Eurasian Journal of Business and Economics, 3(5), 1-25.

Othman, A., Mansor, N., \& Kari, F. (2014). Assessing the performance of cooperatives in Malaysia: an analysis of co-operative groups using a data envelopment analysis approach. Asia Pacific Business Review, (November), 3741. doi:10.1080/13602381.2014.933065

Paxton, J. (2006). Technical Efficiency in the Rural Financial Sector: Evidence from Mexico. The Journal of Developing Areas, 39(2), 101-119. Retrieved from http://www.jstor.org/stable/4193006

ROK. (2012). Kenya's Financial Sector Stability Report, 2011. Nairobi.

Rozzani, N., \& Rahman, R. A. (2013). Determinants of Bank Efficiency: Conventional versus Islamic. International Journal of Business and Management, 8(14), 98-109. doi:10.5539/ijbm.v8n14p98

Sacco Society Regulatory Authority (SASRA). (2013). Sacco Supervision Annual Report, 2013.

Sharma, D., Sharma, A. K., \& Barua, M. K. (2013). Efficiency and productivity of banking sector: A critical analysis of literature and design of conceptual model. Qualitative Research in Financial Markets, 5(2), 195-224. doi:10.1108/QRFM10-2011-0025

Simar, L., \& Wilson, P. W. (1998). Sensitivity Analysis of Efficiency Scores: How to Bootstrap in Non-Parametric Frontier Models. Management Science, 44(1), 4961.

Srairi, A. S. (2010). Cost and profit efficiency of conventional and Islamic banks in GCC countries. Journal of Productivity Analysis, 34(1), 45-62. doi:10.1007/1s112 3-009-0161-7 
Journal of Applied Sciences, Engineering and

Technology for Development. Volume 2, Issue 1

Sufian, F. (2009). Determinants of bank efficiency during unstable macroeconomic environment: Empirical evidence from Malaysia. Research in International Business and Finance, 23, 54-77. doi:10.1016/j.ribaf.2008.07.002

Sufian, F., \& Habibullah, S. (2014). Economic freedom and bank efficiency: does ownership and origins matter? Journal of Financial Regulation and Compliance, 22(3), 174 - 207. doi:10.1108/JFRC-01-2013-0001

Swamy, V. (2012). Determinants of Bank Asset Quality and Profitability: An Empirical Assessment. Retrieved from https://www.researchgate.net/profile/Vighneswara_Swamy/publication/2449885 62

Wheelock, D. C., \& Wilson, P. W. (2011). Are credit unions too small? The Review of Economics and Statistics, 93(4), 1343-1359.

Yadav, R., \& Katib, M. N. (2015). Technical Efficiency of Malaysia's Development Financial Institutions: Application of Two-Stage DEA Analysis. Asian Social Science;, 11(16), 175-182. doi:10.5539/ass.v11n16p175

Zheng, J., Xiaoxuan, L., \& Bigsten, A. (1998). Ownership Structure and Determinants of Technical Efficiency: An Application of Data Envelopment Analysis. Journal of Economic Literature, 484, 465-484. 